\title{
Maintaining and storing encapsulated cells for propagation of Posidonia oceanica (L.) Delile
}

\author{
Marina Carrasco-Acosta, Pilar Garcia-Jimenez* \\ Departamento de Biologia, Facultad de Ciencias del Mar, Instituto de Estudios Ambientales y Recursos Naturales, \\ Universidad de Las Palmas de Gran Canaria, 35017 Las Palmas de Gran Canaria, Canary Islands, Spain
}

\begin{abstract}
In the present study, we have developed an efficient system for regenerating Posidonia oceanica via the storage of free cells at low temperature and the initiation of cell encapsulation. This system could help in solving problems related to the intractable nature of in vitro marine phanerogam regeneration. Free cells from enzyme digestion were preserved with glycerol and DMSO at different concentrations and stored at low temperature. Cell encapsulation was performed with sodium alginate and calcium chloride. First, results showed that optimum cell culture was obtained when the initial cell concentration was $10^{4}$ cells $\mathrm{ml}^{-1}$. Cell scaling allowed exponential growth to produce 2268000 cells at 13 d. Second, treatment based on cell storage with $60 \%$ glycerol plus 1.3 M DMSO was a success. The preserved cells grew and produced 1.96 more cells than the initial cell concentration $\left(10^{4}\right.$ cells $\left.\mathrm{ml}^{-1}\right)$. Third, the encapsulated cells (beads) showed a survival range of 84 to $100 \%$ over $4 \mathrm{yr}$. The divided beads released cells that developed embryos or free cells depending on the culture medium. Cell encapsulation was the only method that was successful to acclimatise the cells to salinity, store artificial material for sowing and obtain embryos. We concluded that encapsulated cells could be used as a starting material for the production of embryos in the regeneration of $P$. oceanica.
\end{abstract}

KEY WORDS: Cell encapsulation · Cryostorage - Free cells · In vitro propagation · Salinity acclimation $\cdot$ Seagrasses $\cdot$ Somatic embryo

\section{INTRODUCTION}

Seagrasses are key species of one of the main marine ecosystems that are declining as a result of anthropogenic activities. Events such as tourism, boating and urbanisation take place on the coastal strip, disturbing the stability of ecosystems and putting phanerogam survival at risk.

Seagrasses mainly propagate through their rhizomes, with a low proliferation rate that gives rise to a low replacement rate (Molenaar \& Meinesz 1995, Hemminga \& Duarte 2000). In addition, the occurrence of sexual reproduction in seagrasses varies among and within species (Balestri et al. 2017), while flowering can also be highly variable in space and time (Balestri 2004, Kilminster et al. 2015, Ruiz et al.

${ }^{*}$ Corresponding author: pilar.garcia@ulpgc.es
2018). The seeds of some seagrass species can have a latency period; in others, such as the genus Posidonia, seed germination begins the moment the seed detaches from the fruit (Orth et al. 2000, Papenbrock 2012). Moreover, the number of seedlings from seed germination is low - probably due to low seed viability and germination, low seedling survival or physical disturbances (Balestri \& Cinelli 2003).

Seagrass meadows have been restored conventionally using explants, also known as ramets, consisting of shoots, rhizomes and roots. Despite successful re-population with ramets, this restoration has been associated with several handicaps such as the time taken to grow explants, damaged donor meadows, plant scarcity, endangered plants and legally protected plants (Possingham et al. 2015). 
Therefore, developing new in vitro culture techniques could be an advantageous source of cell production and seagrass regeneration.

To date, in vitro marine plant regeneration has been done using plant growth regulators to produce disorganised masses that trigger bud formation (Garcia-Jimenez et al. 2006). For some terrestrial plant species and seagrasses (marine phanerogams), the induction of disorganised masses is severely complicated despite the use of non-conventional growth regulators such as thidiazuron (TDZ) and picloram (Garcia-Jimenez et al. 2006). In seagrasses, culture in the presence of TDZ has been established with $0.5 \mathrm{~cm}$ explants of Cymodocea nodosa, but massive shoot propagation has not been achieved. In general, these explants are affected by experimental conditions, showing non-uniform responses (GarciaJimenez et al. 2006).

Approaches based on seedlings, obtained from seagrass seeds, have also been reported (Balestri et al. 1998, Zarranz et al. 2010). A priori seeds can be recovered, germinated in vitro and, after an acclimation period, transplanted to the field. The use of plant growth regulators like gibberellic acid in in vitro culture reported a moderate leaf growth, while most cultures supplemented with auxins and kinetin failed (Zarranz et al. 2010, Zarranz et al. 2012). This lack of efficient in vitro regeneration systems is the principal bottleneck hampering efficient seagrass recovery because, to date, only ramets, which are dependent on meadows, and seedlings, which depend on seed availability, are available.

To circumvent these issues, procedures to force somatic embryogenesis and plant regeneration from free cells with complete or partially digested cell walls have been developed in C. nodosa (Zarranz et al. 2010, Zarranz et al. 2012). A first point of reference was that young embryonic explants from seeds of $C$. nodosa were digested with an enzyme cocktail. Despite the recovery of viable cells in C. nodosa, 2 barriers still have to be overcome. The first barrier is the requirement for salt, since cells are isolated in freshwater media. As growth advances, sodium chloride is needed as a physiological requirement due to the halophytic nature of $C$. nodosa. The second barrier is that adding salt triggers excessive growth of contaminants due to the halophytic nature of the contaminants associated with the explant (Zarranz et al. 2012).

Cell encapsulation can be a pathway for contaminant-free salinity adaptation. Moreover, the encapsulation of meristem cells of marine plants could enhance the potential for cell production and subse- quent propagation. It may also provide a means for maintaining and storing encapsulated cells, as a synthetic seedstock, for producing clones for vegetative propagation. In this work, we have adopted a broad concept of synthetic seed (as used in terrestrial plants) as any vegetative propagule with an artificial coating trapped in a nutrient medium supplying carbon sources, growth regulators and any vitamin and mineral nutrient supplement. In terrestrial plants, the proposal to encapsulate somatic embryos has made handling easier and impedes the transmission of disease (Rai et al. 2009). The synthetic embryo coating was mainly based on thermal gels and polymerisation in the presence of a crosslinking agent. Sodium alginate in the presence of calcium chloride is the most widely used of the polymerising gels (Rai et al. 2009). Others such as hollow beads made of carboxy methylcellulose have not been very satisfactory (Patel et al. 2000, Pandey \& Chand 2004, Winkelmann et al. 2004). These endeavours could be good alternatives for regenerating seagrasses using organogenesis, somatic and zygotic embryogenesis and shoot production. The aim of this study is to preserve, encapsulate and germinate cells of Posidonia oceanica for the first time. To do this, we preserve cells at low temperature, encapsulate cells in alginate beads and allow cells to acclimate to salinity and germinate. Our hypothesis is that encapsulated cells could be a promising alternative for regenerating seagrasses, and there would be opportunities for a synthetic seedstock.

\section{MATERIALS AND METHODS}

Fragments of Posidonia oceanica, containing leaves and rhizomes, were collected by scuba diving in a meadow located at Cala El Racó (Alicante) $\left(38^{\circ} 38^{\prime}\right.$ 7.81" N, $0^{\circ} 4^{\prime} 14.53^{\prime \prime} \mathrm{E}_{\text {; }}$ Spain). Once collected, fragments of $P$. oceanica were transported to the laboratory in crystal blue pearls hydrated with seawater (water crystal pearls, Amazon.co.uk).

\subsection{Cell culture}

\subsubsection{Free and viable cell culture}

The basal part of leaves including the zone of cell division (meristem; Fig. S1 in the Supplement at www.int-res.com/articles/suppl/b030p047_supp.pdf) was superficially sterilised with ethanol $(70 \%, 1 \mathrm{~min})$ and sodium hypochlorite $(2 \%, 30 \mathrm{~min})$ and washed 
with autoclaved distilled water (3 times, 1 min each). Then, they were cut into small pieces (approx. $0.5 \mathrm{~cm}$ each, $\mathrm{n}=10$ ) and pricked several times using a sterile scalpel to facilitate rapid enzyme digestion.

Sections were plasmolysed and digested by using the method described by Zarranz et al. (2012). Plasmolysis was carried out at $26^{\circ} \mathrm{C}$ for 5 min using mannitol as a plasmolyticum ( $\mathrm{pH}$ 5.8). Then, a filter-sterilized enzyme solution containing $1 \%(\mathrm{w} / \mathrm{v})$ of cellulase $7.5 \mathrm{U} \mathrm{mg}^{-1}$ and hemicellulose $1.5 \mathrm{U} \mathrm{mg}^{-1}$ was added. The mixture was incubated overnight in an orbital shaker in darkness at $26 \pm 1^{\circ} \mathrm{C}$. Digested cells were filtered through a $37 \mu \mathrm{m}$ steel sieve (Sigma) and centrifuged (1000 $\times$ g, $5 \mathrm{~min})$. Cells were then washed with Murashige and Skoog medium containing sucrose $3 \%$ (henceforth MS, Murashige \& Skoog 1962) 3 times and placed in the culture chamber for $24 \mathrm{~h}$ at $19^{\circ} \mathrm{C}$ until they were used.

The yield and viability of cells were assessed after staining with $0.4 \%(\mathrm{w} / \mathrm{v})$ trypan blue in phosphatebuffered saline at $1 \%(\mathrm{pH} 7.4)$. Trypan blue solution was filtered and used in a ratio of 1:1 with the culture medium. An aliquot of trypan blue-treated cell suspension was applied to a hemocytometer, and the yield was expressed as the concentration of viable cells (cells ml ${ }^{-1}$ ).

\subsubsection{Growth kinetics of isolated cells and scaling cell culture}

A cell growth curve was designed to analyse the behaviour of isolated cells by appraising the period of maximum cell growth. Two approaches were performed, depending on culture medium renewal and the initial cell concentration (Fig. 1).

Regarding renewal of the culture medium, $2.5 \mathrm{ml}$ fresh media was added in a ratio of 1:1 (fresh:aged media) every $4 \mathrm{~d}$. Culture medium without renewal, known as the aged medium, was used as a control. In all cases, the final culture volume was $5 \mathrm{ml}$, and viable cells were quantified as previously described (Section 2.1.1).

To continue the analysis of cell behaviour, cells in the log growth state (ca. $4 \times 10^{6} \mathrm{cells} \mathrm{ml}^{-1}$ ) were used to establish new cultures at different initial cell concentrations of $10^{5}, 0.5 \times 10^{5}$ and $10^{4}$ cells ml ${ }^{-1}$ and $10^{6}$ cells $\mathrm{ml}^{-1}$ as a control.

Cell scaling was also carried out to test if cells were able to maintain exponential growth under conditions in which the initial cell concentration and final volume of culture medium did not limit growth. Thus, cells in the log growth state at $10^{4} \pm 1100$ cells ml$^{-1}$ were scaled up to $120 \mathrm{ml}$ final volume of the culture medium. Ratios between cell concentration and final volume were established as 1:3, 1:6, 1:18 and 1:36 every $4 \mathrm{~d}$ for $16 \mathrm{~d}$. A proportion of 1:10 (volume of cell concentration:final volume of culture medium) was also established in all cases.

All assays were repeated independently 3 times. All media used for cell culture were autoclaved at $121^{\circ} \mathrm{C}$ for $20 \mathrm{~min}$. The new cell culture was always established with $3 \mathrm{ml}$ of the preceding cell culture obtained after a slight centrifugation at $1000 \times g$ for 5 min.

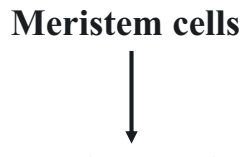

Plasmolysis and digestion

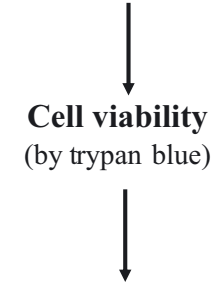

\section{Growth kinetic of isolated cells}

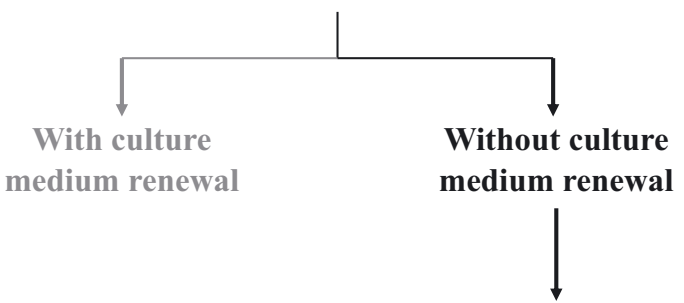

Optimisation of culture initial cell concentration

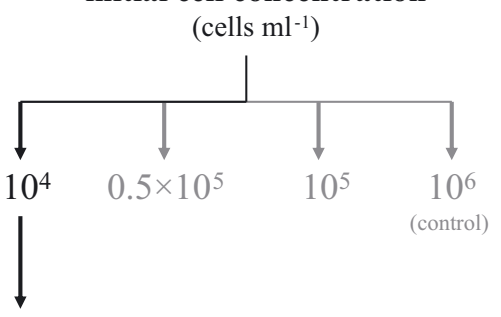

Scaling of cell culture

(dilutions 1:3, 1:6, 1:18, 1:36; every 4 d)

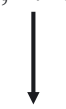
Growth kinetic
(for $16 \mathrm{~d}$ )

Fig. 1. Schematic procedure to obtain free cells and optimisation of cell culture. Grey and black values were tested in this work. Black took priority 


\subsection{Cell storage}

For low-temperature storage, DMSO (Sigma) at 2 concentrations $(0.6$ and $1.3 \mathrm{M}$ ) and glycerol (Sigma) at each of the following concentrations, 50 and $60 \%$, were tested in combination as cryoprotectors (Fig. 2). Cryotubes containing cells at a concentration of $10^{6}$ cells $\mathrm{ml}^{-1}$ were placed at $-20^{\circ} \mathrm{C}$ for $5 \mathrm{~min}$ and then at $-80^{\circ} \mathrm{C}$ for $24 \mathrm{~h}$, for freezing.

Cell recoveries were assayed by thawing cryotubes in a culture chamber at $20^{\circ} \mathrm{C}$ for $24 \mathrm{~h}$ in darkness (henceforth direct method). Otherwise, cryotubes were thawed at $-20^{\circ} \mathrm{C}$ for $5 \mathrm{~min}, 4^{\circ} \mathrm{C}$ for $5 \mathrm{~min}$ and $20^{\circ} \mathrm{C}$ for $24 \mathrm{~h}$ in a culture chamber in darkness (henceforth indirect method). Cell recovery was carried out using centrifugation at $1000 \times g$ for $5 \mathrm{~min}$, and cells were washed twice with MS. Cells without DMSO and glycerol were then cultured in Petri dishes in darkness for $24 \mathrm{~h}$ to reach complete recovery. A concentration of $10^{4}$ cells $\mathrm{ml}^{-1}$ was then used to establish the cultures and to quantify cell recovery. The cell recovery was expressed as cells $\mathrm{ml}^{-1}$ by counting viable cells with trypan blue every $2 \mathrm{~d}$ for $15 \mathrm{~d}$.

To reduce cell recovery time, cell storage with $60 \%$ glycerol plus 1.3 M DMSO was optimised with modifications to the indirect recovery method (Fig. 2). Thus, after freezing, cells were thawed at (1) $37^{\circ} \mathrm{C}$ for $10 \mathrm{~min}$ (henceforth treatment 1); (2) $-20^{\circ} \mathrm{C}$ for $5 \mathrm{~min}$ and $4^{\circ} \mathrm{C}$ for $5 \mathrm{~min}$ (henceforth treatment 2); and (3) $-20^{\circ} \mathrm{C}$ for $5 \mathrm{~min}, 4^{\circ} \mathrm{C}$ for $5 \mathrm{~min}$ and $20^{\circ} \mathrm{C}$ for $24 \mathrm{~h}$ as a control (henceforth treatment 3).

Furthermore, assays using 1.3 M DMSO as the only cryoprotector were also tested at $37^{\circ} \mathrm{C}$ for $10 \mathrm{~min}$ (henceforth treatment 4 ) and at $-20^{\circ} \mathrm{C}$ for $5 \mathrm{~min}, 4^{\circ} \mathrm{C}$ for $5 \mathrm{~min}$ and $20^{\circ} \mathrm{C}$ for $24 \mathrm{~h}$ (henceforth treatment 5).

For all treatments, cell recovery was completed after $24 \mathrm{~h}$ in darkness as described above. Cell concentration was quantified once a day for $4 \mathrm{~d}$.

All assays were repeated independently 3 times for each combination of cryoprotector and treatment.

\subsection{Cell encapsulation}

Isolated cells at concentrations in the range of 2 to $5 \times 10^{6}$ cells ml ${ }^{-1}$ were suspended in $3 \% \mathrm{w} / \mathrm{v}$ of sodium alginate (Sigma) in liquid MS (pH 5.7) with $30 \mathrm{~g} \mathrm{l}^{-1} \mathrm{su}-$ crose and then carefully dropped into $75 \mathrm{mM} \mathrm{CaCl}_{2}$ solution (Sigma) as a complexing agent, using a pipette (Lei et al. 2015). To complete the complexation process, the cells in a suspension of sodium alginate plus $\mathrm{CaCl}_{2}$ were gently shaken for 20 to $30 \mathrm{~min}$ using a rotary shaker. Spherical artificial beads with cells encapsulated in them (henceforth beads) were then obtained. To complete the process, the excess calcium chloride was removed, and the beads were washed 3 times with sterile MS medium. Beads were then placed on a filter paper in a laminar flux chamber for $10 \mathrm{~min}$. Beads were kept in $50 \mathrm{ml} \mathrm{MS} \mathrm{medium} \mathrm{in}$
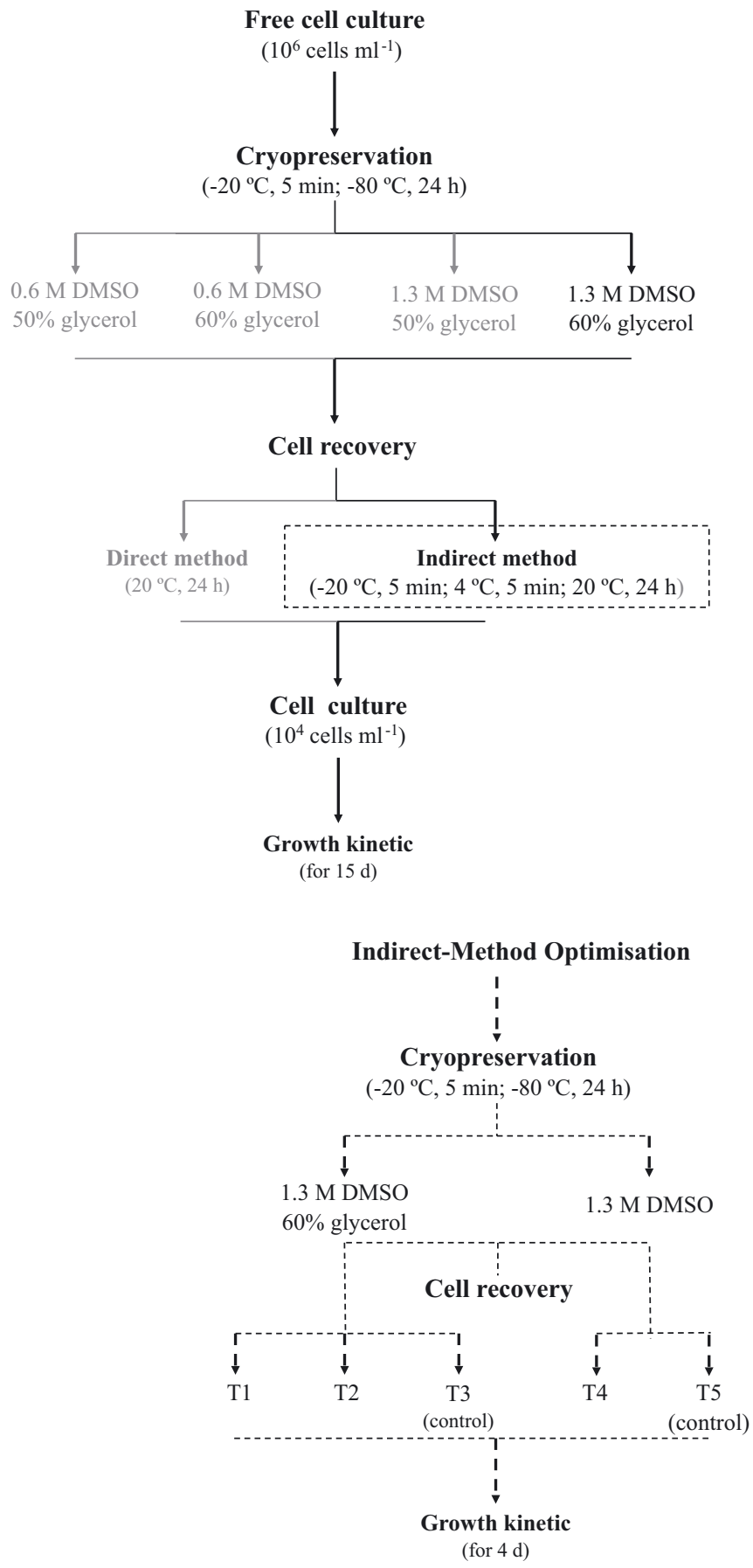

Fig. 2. Schematic procedure to cryopreserve cells at low temperature and recover them through 2 methods (direct and indirect). In detail, optimization of indirect method. Continuous and dashed lines are indicative of different approaches 
darkness and used for salinity acclimation when necessary. If not, beads were placed on solidified MS basal medium supplemented with hormones for storing. To determine the viability of encapsulated cells, 3 beads were randomly withdrawn, each was cut into 4 pieces and cell concentration was determined 3 times per year (Fig. 3).

All the chemicals and glass goods used in this experiment were sterilised in the autoclave, and the whole encapsulation procedure was done under a laminar air flow hood to avoid exogenous contaminations. All assays were repeated independently 3 times with 15 beads per plate.

\subsection{Acclimation of encapsulated cells}

Beads were randomly selected, gently washed in MS medium and placed on a sterilised slide to be cut into 4 pieces. Then, 4 portions were cultured in liquid MS medium supplemented with $90 \mathrm{~g} \mathrm{l}^{-1}$ sucrose, naphthaleneacetic acid $10^{-5} \mathrm{M}$ and glutathione $10^{-5} \mathrm{M}$ in an orbital shaker. Sodium chloride was gradually added to reach $36 \mathrm{psu}$. Salinity acclimation was performed for $4 \mathrm{wk}$ with the addition of $0.2 \mathrm{M} \mathrm{NaCl}$ and proline $200 \mathrm{mM}$ every $2 \mathrm{wk}$.

Furthermore, the culture medium containing salinity-acclimated cells was also supplemented with indole-3-butyric acid (IBA, 10-5 $\mathrm{M}$ ) for $1 \mathrm{~h}$ and then cells cultured with polyethylene glycol $6 \%$. Controls were carried out in MS media without sodium chloride, in media without IBA and without polyethylene glycol. All assays were repeated independently 3 times.

\subsection{Data analysis}

Statistical comparisons of data were performed using R software (https://www.r-project.org). Data (mean $\pm \mathrm{SD}$ ) were calculated and subjected to 1-way ANOVA, followed by post hoc tests (Tukey's HSD and Dunnett's T3) or non-parametric Mann-Whitney (Wilcoxon) $W$-tests. Tests were used to detect significant differences $(\mathrm{p} \leq 0.01)$ in different treatments for cell storage and recovery at low temperature and to compare growth in media with and without renewal.

\section{RESULTS}

\subsection{Cell culture}

Free and viable cell cultures were obtained from enzyme digestion. The cell viability quantified by trypan blue revealed a cell concentration of 1108444 \pm 104889 cells ml${ }^{-1}$. The growth of free cells of Posidonia oceanica started with a lag phase of ca. $2 \mathrm{~d}$ followed by exponential growth that reached its maximum at $4 \mathrm{~d}$. The cell concentration was then 4 times the initial cell concentration $\left(4 \times 10^{6} \mathrm{cells} \mathrm{ml}^{-1}\right)$. Afterwards, growth continued until it stabilised by $10 \mathrm{~d}$ (Fig. 4). The rate of cell growth was $4 \times 10^{6} \mathrm{~d}^{-1}$. Cells grown in renewed medium (fresh medium) showed a growth rate that was not significantly $(p>0.01)$ different from that reported in the aged medium $\left(3 \times 10^{6} \mathrm{~d}^{-1}\right)$ (Fig. 4).

To assess the extent to which initial cell concentration can affect growth, the cell suspension in the log phase (ca. $4 \times 10^{6}$ cells ml $^{-1}$ ) was diluted to different concentrations as follows: $10^{4}, 0.5 \times 10^{5}$ and $10^{5}$ cells $\mathrm{ml}^{-1}$ and $10^{6}$ cells ml $^{-1}$ as a control (Fig. 5). Results showed that cells at an initial concentration of $10^{4}$ cells $\mathrm{ml}^{-1}$ were able to continue growing and increased by $40 \%$. Significant differences $(p \leq 0.01)$ in growth 


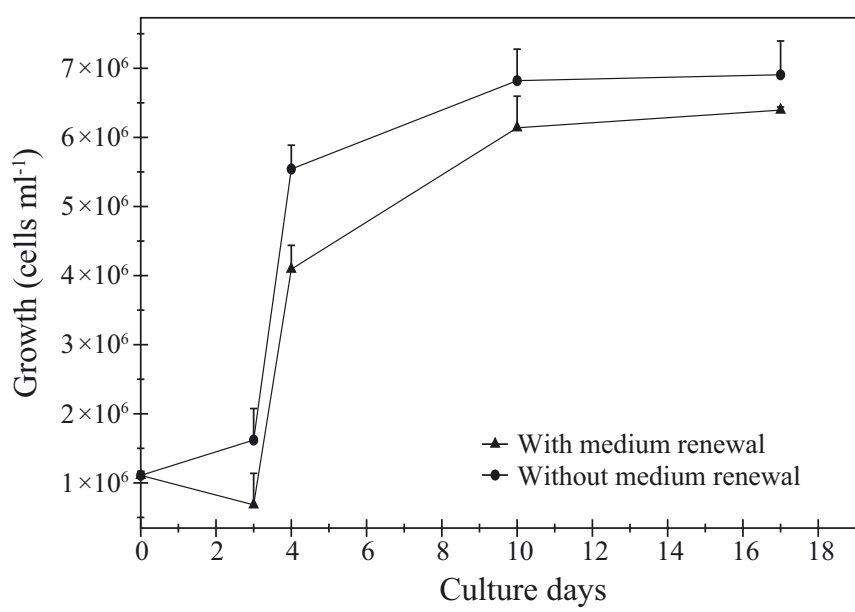

Fig. 4. Growth of free cells (in cells $\mathrm{ml}^{-1}$ ) of Posidonia oceanica cultured in Murashige and Skoog medium (Murashige \& Skoog 1962) with (fresh medium) and without (aged medium) renewal. Data are mean $\pm \mathrm{SD}, \mathrm{n}=3$

were determined between 1 and $5 \mathrm{~d}$ of culture after cells reach the log phase compared to other initial concentrations. The maximum cell concentration was estimated to be $15185 \pm 484$ cells ml $^{-1}$ at $2 \mathrm{~d}$ of culture (Fig. 5). Growth was restricted, on the other hand, when the initial cell concentrations were higher than $10^{4}$ cells $\mathrm{ml}^{-1}$. So, results showed that once cells reached maximum growth (log state and maximum cell concentration), the growth diminished (Fig. 5).

Cell scaling was able to keep cells growing exponentially (Fig. 6). Results showed that the addition of fresh medium combined with the balanced proportion of cell volume: final volume of the culture medium recipient (1:10) rendered ca. $7000 \pm 400$ cells $\mathrm{ml}^{-1}$ and 2 to 2.4 times the number of cells every $4 \mathrm{~d}$ (Fig. 6). This meant that the final cell count at $13 \mathrm{~d}$ was $2268000 \pm 1336$ cells in a final volume of $60 \mathrm{ml}$.

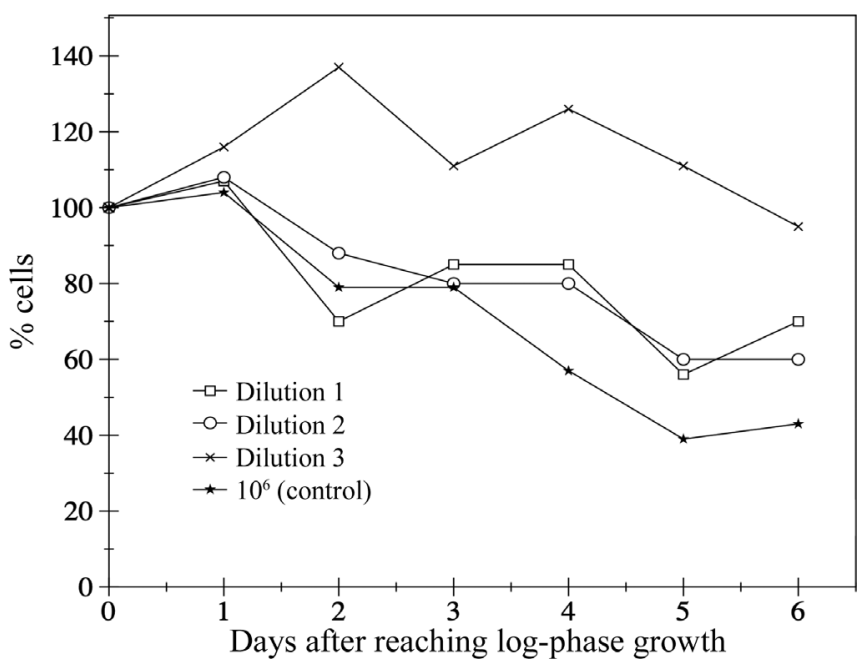

Fig. 5. Growth of log-phase cells (in \% cells) of Posidonia oceanica at different initial cell concentrations. Initial cell concentrations (in cells ml ${ }^{-1}$ ) were $0.5 \times 10^{5}$ (dilution 1 ), $10^{5}$ (dilution 2) and $10^{4}$ (dilution 3); $100 \%$ : initial cell concentration of $10^{4}$ cells ml ${ }^{-1}$. A control of log-phase cells at $10^{6}$ cells $\mathrm{ml}^{-1}\left(100 \%\right.$ : initial cell concentration of $10^{6}$ cells $\left.\mathrm{ml}^{-1}\right)$ was also established. Significant differences in growth were determined between 1 and $5 \mathrm{~d}(\mathrm{p}<0.01)$ for cultures at $10^{4}$ cells $\mathrm{ml}^{-1}$ compared to other cultures

Beyond $13 \mathrm{~d}$, the cell concentration decreased 1.85 times, and cell concentration decreased to $2100 \pm 350$ cells $\mathrm{ml}^{-1}$ in $120 \mathrm{ml}$ final volume (Fig. 6). When the culture was abandoned, cell clumps (ca. 0.5-1 $\mathrm{mm}$ in diameter) appeared.

\subsection{Cell storage}

After thawing and keeping the cells in darkness for $24 \mathrm{~h}$, viable cells through the direct method were quantified. Cells preserved with $60 \%$ glycerol plus 1.3 M DMSO showed higher cell numbers than other

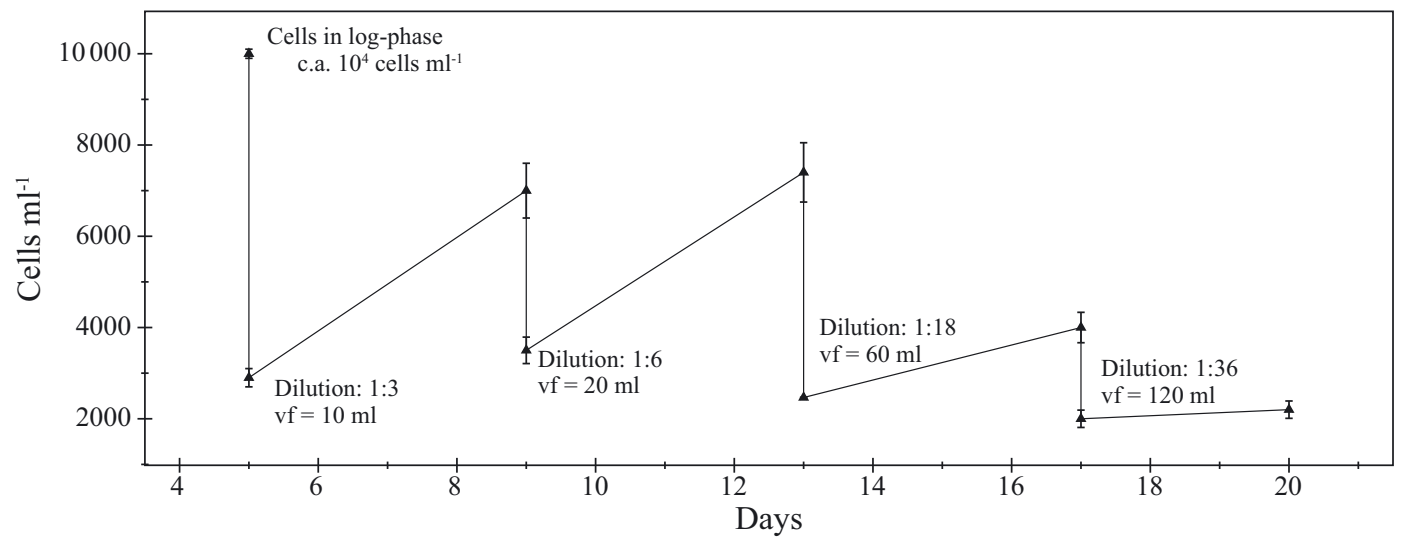

Fig. 6. Cell scaling of cells of Posidonia oceanica in the log phase at an initial cell concentration of $10^{4} \mathrm{cells}^{-1}$. vf: final volume 


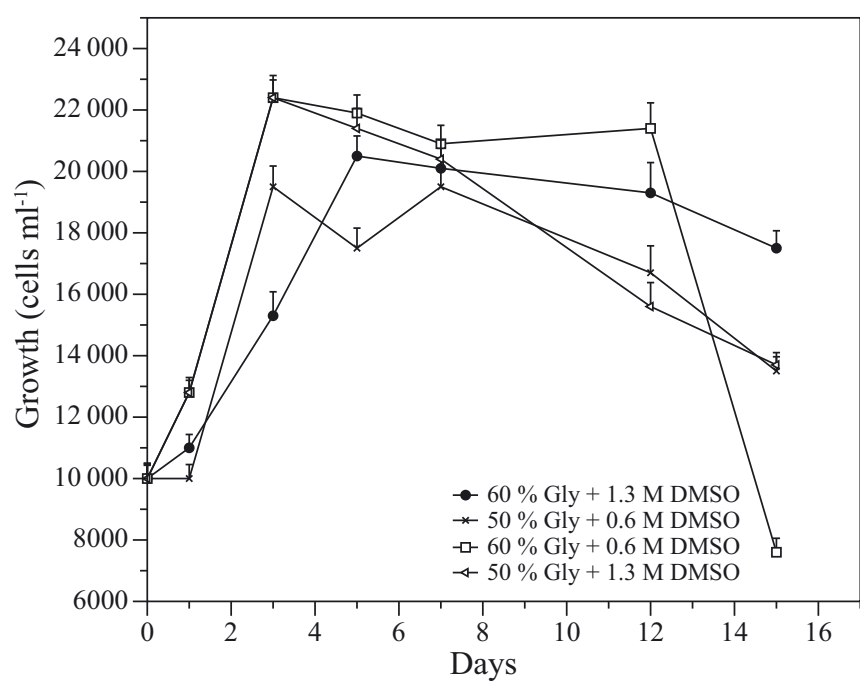

Fig. 7. Cell growth (cells ml $\mathrm{m}^{-1}$ ) of cells of Posidonia oceanica preserved with 4 concentrations of cryoprotectants and thawed through the direct method $\left(20^{\circ} \mathrm{C}\right.$ for $24 \mathrm{~h}$ in darkness). Gly: glycerol

cryopreservative concentrations at the end. Thus, the highest cell concentration was reported at $5 \mathrm{~d}$ with $20500 \pm 3400$ cells ml $^{-1}$ at $60 \%$ glycerol and $1.3 \mathrm{M}$ glycerol. This indicates a cell concentration increment of 1.75 times compared to the initial concentration $\left(10^{4}\right.$ cells ml $\left.{ }^{-1}\right)$. After that, cell growth was maintained at $17500 \pm 2865$ cells ml $^{-1}(\mathrm{p} \leq 0.01)$ at $15 \mathrm{~d}$ (Fig. 7). Cells from other cryopreservative concentrations decayed at $12 \mathrm{~d}$, giving the lowest cell concen-

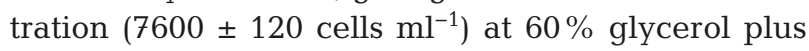
0.6 M DMSO (Fig. 7).

The indirect method $\left(-20^{\circ} \mathrm{C}\right.$ for $5 \mathrm{~min}, 4^{\circ} \mathrm{C}$ for $5 \mathrm{~min}$ and $20^{\circ} \mathrm{C}$ for $24 \mathrm{~h}$ ) also showed that the combination of $60 \%$ glycerol plus $1.3 \mathrm{M}$ DMSO as cryoprotectors rendered a cell concentration of $19600 \pm 4561$ cells $\mathrm{ml}^{-1}$ at $14 \mathrm{~d}$ (end time). This meant a cell concentration increment of 1.96 times $(\mathrm{p} \leq 0.01)$ against the initial preserved cells $\left(10^{4}\right.$ cells $\mathrm{ml}^{-1}$; Fig. 8$)$. The other treatments showed a reduction of cell concentration at $9 \mathrm{~d}$ onwards (Fig. 8).

Adaptations of the indirect method to recover cells quicker showed that cell concentration in all treatments (treatments 1-5) diminished at $1 \mathrm{~d}$ after complete recovery (without DMSO and glycerol). Unlike treatments 1 and 2, cells from treatment 3 were able to recover and grow at a rate of $2.4 \times 10^{3} \mathrm{~d}^{-1}$ and maintain cell concentrations similar to the initial stage of culture $\left(10^{4}\right.$ cells ml ${ }^{-1}$, Fig. 9) at $2 \mathrm{~d}$.

When only 1.3 M DMSO was used, cells thawed at $-20^{\circ} \mathrm{C}$ for $5 \mathrm{~min}, 4^{\circ} \mathrm{C}$ for $5 \mathrm{~min}$ and $20^{\circ} \mathrm{C}$ for $24 \mathrm{~h}$ (treatment 5) were also able to continue growing at a rate of $1.5 \times 10^{3} \mathrm{~d}^{-1}\left(10456 \mathrm{cells} \mathrm{ml}^{-1}\right.$ at $\left.2 \mathrm{~d}\right)$. Al-

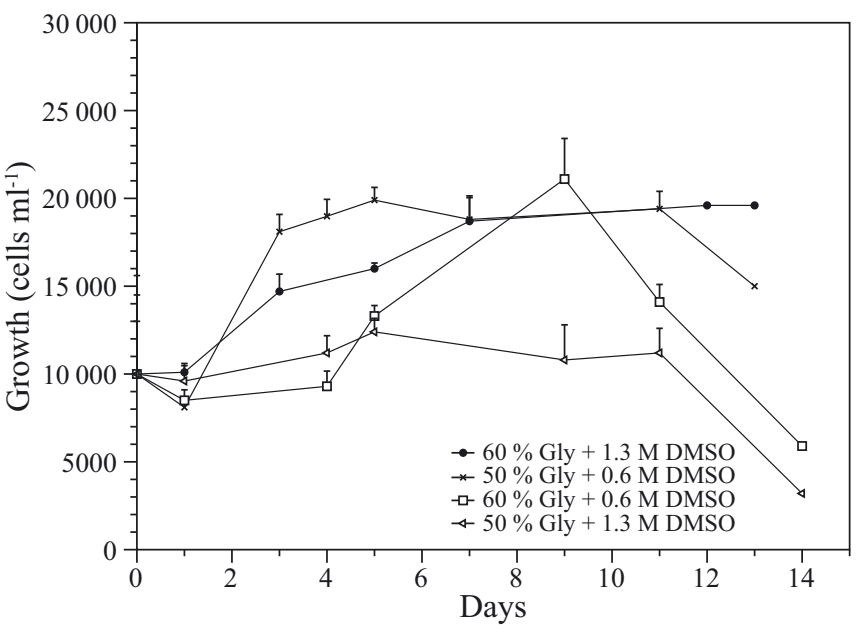

Fig. 8. Cell growth (cells ml $\mathrm{m}^{-1}$ ) of cells of Posidonia oceanica preserved with 4 concentrations of cryoprotectants and thawed through the indirect method $\left(-20^{\circ} \mathrm{C}\right.$ for $5 \mathrm{~min}, 4^{\circ} \mathrm{C}$ for $5 \mathrm{~min}$ and $20^{\circ} \mathrm{C}$ for $24 \mathrm{~h}$ ). Gly: glycerol

though the growth rate was lower in this treatment than in treatment $3(60 \%$ glycerol plus $1.3 \mathrm{M}$ DMSO under the same thawing conditions), the final cell concentration was higher $(\mathrm{p} \leq 0.01)$ at $4 \mathrm{~d}$. Cells in $1.3 \mathrm{M}$ DMSO and recovered at $37^{\circ} \mathrm{C}$ (treatment 4 ) collapsed and died (Fig. 9).

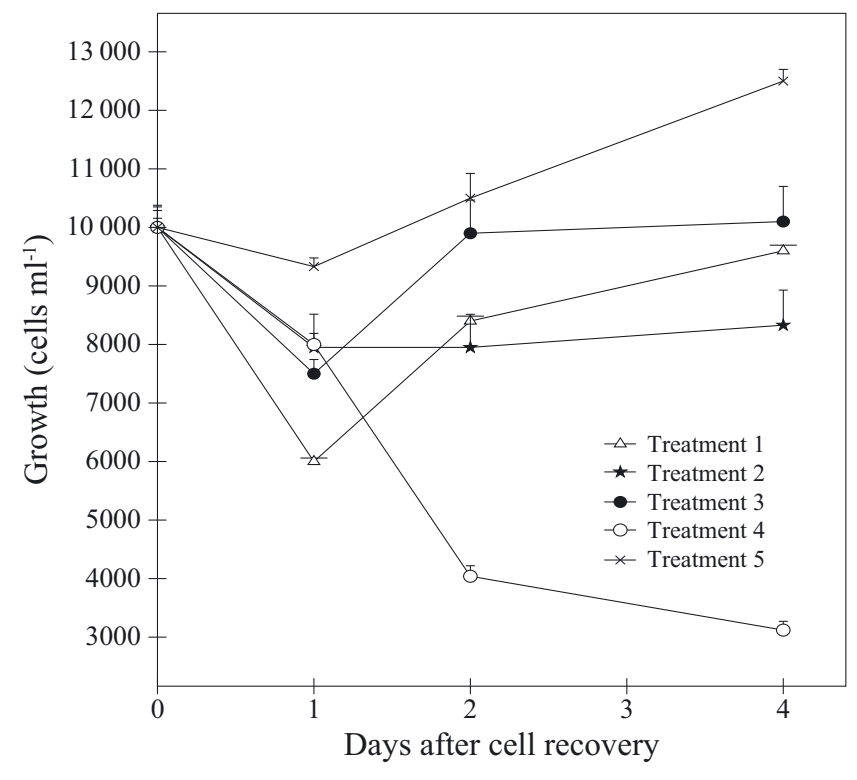

Fig. 9. Cell growth (cells ml-1) of cells of Posidonia oceanica preserved at $60 \%$ glycerol plus $1.3 \mathrm{M}$ DMSO (treatments 1-3) and 1.3 M DMSO (treatments 4 and 5) and further recovered through adaptations of the indirect method. Treatment 1: thawed at $37^{\circ} \mathrm{C}$ for $10 \mathrm{~min}$; treatment 2: thawed at $-20^{\circ} \mathrm{C}$ for $5 \mathrm{~min}$ and $4^{\circ} \mathrm{C}$ for $5 \mathrm{~min}$; treatment 3: thawed at $-20^{\circ} \mathrm{C}$ for $5 \mathrm{~min}, 4^{\circ} \mathrm{C}$ for $5 \mathrm{~min}$ and $20^{\circ} \mathrm{C}$ for $24 \mathrm{~h}$; treatment 4: thawed at $37^{\circ} \mathrm{C}$ for $10 \mathrm{~min}$; treatment 5 : thawed at $-20^{\circ} \mathrm{C}$ for $5 \mathrm{~min}, 4^{\circ} \mathrm{C}$ for $5 \mathrm{~min}$ and $20^{\circ} \mathrm{C}$ for $24 \mathrm{~h}$ 
Beads of cells encapsulated in sodium alginate have been stored in solid MS medium for $4 \mathrm{yr}$ (Fig. 10A). Cells from encapsulates survived and showed 84 to $100 \%$ survival after $4 \mathrm{yr}$, as random controls revealed (Fig. 10B; Table 1), compared with the initially encapsulated cell concentration $\left(10^{6}\right.$ cells $\mathrm{ml}^{-1}$; Fig. S2A,B). Time of storage had no significant influence on the survival of encapsulated cells (Table 1).

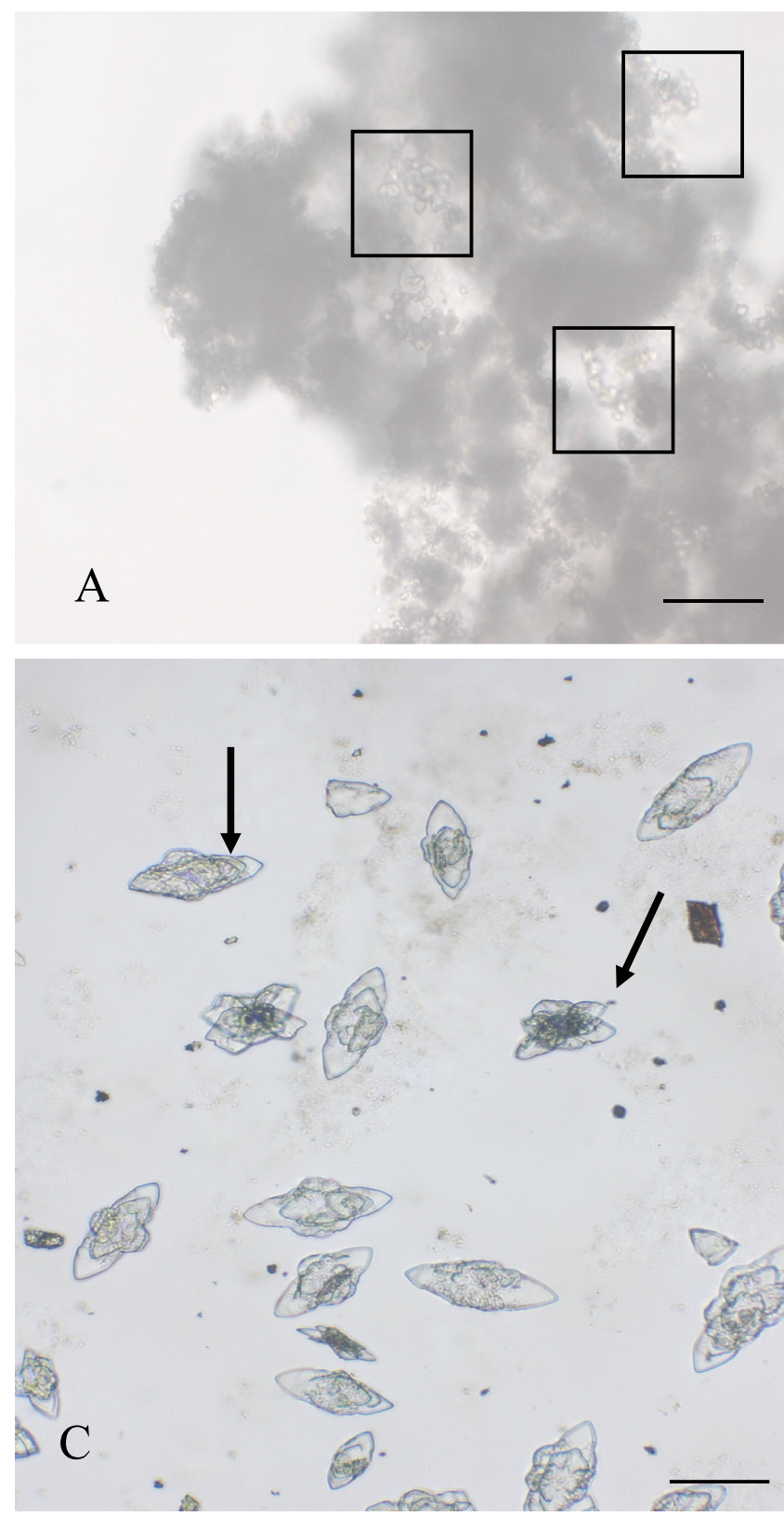

Table 1. Cell survival (\%) of Posidonia oceanica released from each of 3 beads randomly withdrawn from culture throughout 4 yr. $100 \%=10^{6}$ cells ml $^{-1}(p>0.01)$

\begin{tabular}{|lrrr|}
\hline \multirow{2}{*}{ Year } & \multicolumn{3}{c|}{ Bead } \\
\cline { 2 - 4 } & 1 & 2 & 3 \\
\hline 1 & 100 & 100 & 87 \\
2 & 78 & 99 & 100 \\
3 & 99 & 99 & 92 \\
4 & 100 & 100 & 84 \\
\hline
\end{tabular}
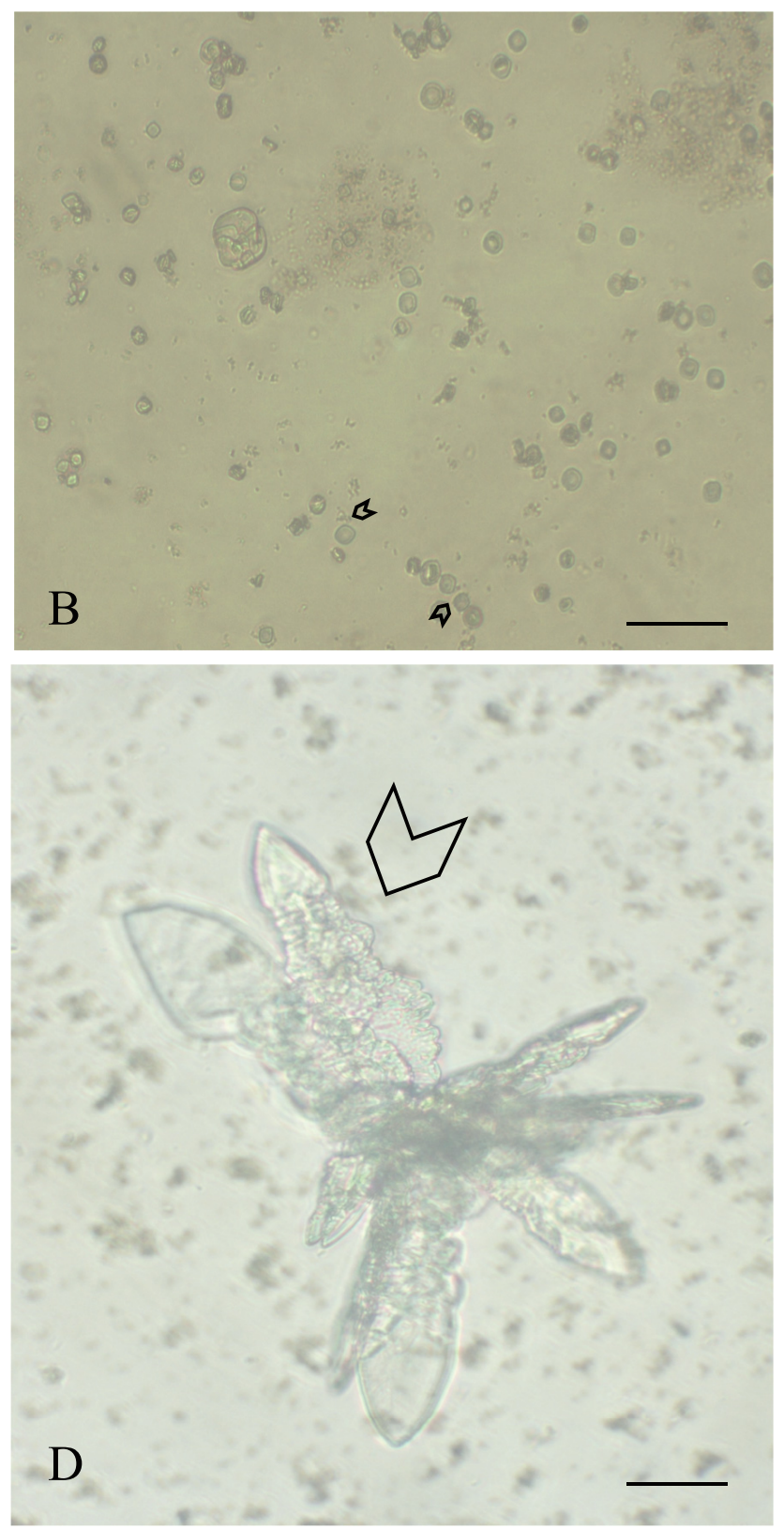

Fig. 10. Encapsulated cells of Posidonia oceanica acclimated to salinity. (A) Sectioned beads containing cells (square). (B) Cells from encapsulates in liquid Murashige and Skoog (MS) medium. Small arrows indicate cells in division. (C) Pre-embryos (1 mo old) from cell encapsulates in liquid MS medium (arrows). (D) Pre-embryo showing small putative shoots (arrow). Scale bar in all $=18 \mu \mathrm{m}$ 


\subsection{Acclimation of encapsulated cells}

Non-encapsulated cells were unable to acclimate to salinity and died. Meanwhile, cell beads cut in liquid MS medium were able to remain in MS without $\mathrm{NaCl}$, but no growth was reported.

Culture of cells from sectioned beads in MS liquid medium proceeded in the presence of $\mathrm{NaCl}$ as the cells grew. The surrounding medium could be modified completely to promote cell acclimation to salinity. The medium was simply removed with a pipette without damaging the beads, and fresh medium was added at the corresponding $\mathrm{NaCl}$ concentration twice a week to reach the final concentration. Cell encapsulation proved to be beneficial for cell division and for keeping viable cells for more than $1 \mathrm{yr}$.

Cells developed asynchronously as small preembryogenic masses. These pre-embryogenic masses became dispersed in liquid medium for months (Fig. 10C). Approximately $80 \pm 5$ small pre-embryogenic masses were reported in 1 mo (Fig. 10C). Fur- thermore, the formation of pre-embryogenic masses was triggered by the pulse of auxin at high concentration (IBA, $10^{-5} \mathrm{M}$ ). Pre-embryos continued to grow and become translucid in the first months (Fig. S2C,D). These pre-embryogenic masses were ca. $5 \mu \mathrm{m}$ in length. Pre-embryogenic masses (average of ca. 3035 masses) showed small needles as putative shoots in a maximum range of 3 to 6 shoots at $5 \mathrm{mo}$ (Fig. 10D). These pre-embryogenic masses were then cultivated in solid media and turned opaque and formed small plantlets which grew towards light at 12 mo. As conspicuous increase in size was observed under a stereomicroscope, these pre-embryogenic masses were henceforth named embryos (ca. 22-25 embryos; Fig. 11A). The presence of polyethylene glycol in the culture medium, on the other hand, promoted the growth of individual $P$. oceanica cells in the presence of $\mathrm{NaCl}$. The individual cells turned spherical and densely cytoplasmic. Initial cell division was observed as soon as 5 to $6 \mathrm{~d}$ with subsequent development at 5 to 6 wk (Fig. 11B,C).

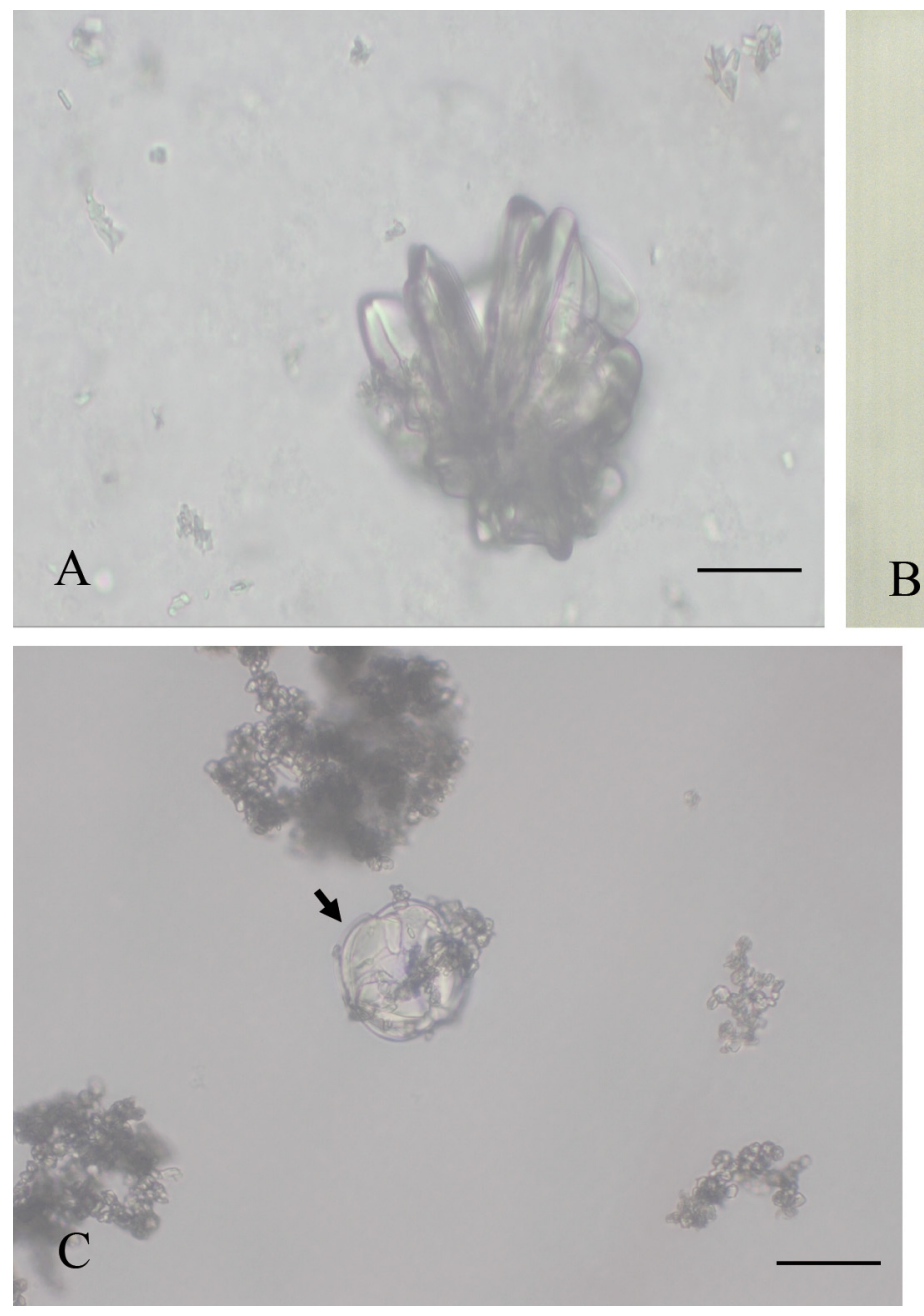

Fig. 11. (A) Embryo of Posidonia oceanica in solid Murashige and Skoog (MS) medium. Scale bar $=570 \mu \mathrm{m}$. (B) Cells cultured in liquid MS medium. Detail of a cell in division at 5 to $6 \mathrm{~d}$ growing in medium containing polyethylene glycol (arrow). (C) Linear 3 cells at 5 to $6 \mathrm{wk}$ (arrow). Scale bar in (B) and (C) $=18 \mu \mathrm{m}$ 


\section{DISCUSSION}

In comparison with the ample literature on establishing cell cultures for herbal plant regeneration (Nalawade et al. 2003, Ali et al. 2018), and in some cases for freshwater plants like Anubias (Pongchawee et al. 2006) and Potamogeton (Staal et al. 1988), nothing is known for seagrasses except the advances reported in Cymodocea nodosa (Garcia-Jimenez et al. 2006, Zarranz et al. 2010, Zarranz et al. 2012). In light of these findings, this study shows that cells of Posidonia oceanica can be used for micropropagation when an optimum starting cell concentration is used. As culture progresses, cell cultures can be successfully scaled up to allow cell growth (Fig. 6). Cell growth usually occurs in the log phase, which is associated with eliciting further embryo development, as this phase supports the inclusion or elimination of growth regulators and an increase in sucrose levels, among others. Otherwise, cell cluster aggregation hampers nutrient diffusion, causing cell death in nonscaled media. Hence, the possibility of scaling up the culture is an advantage, as cells could be used as a source of material for the micropropagation of $P$. oceanica. Therefore, our next steps are aimed at assessing whether cell storage at low temperature and cell encapsulation can somehow affect cell survival and growth.

One factor that obviously affects cell storage is the choice of cryoprotectors. DMSO and glycerol were chosen as they reduce the amount of ice formed at any temperature, permeate membranes rapidly and have low toxicity (Pegg 2007). Cell storage at low temperature of $P$. oceanica was reported a success, as cells were recovered at the same order of magnitude $\left(10^{6}\right.$ viable cells $\left.\mathrm{ml}^{-1}\right)$ as that of the cell concentration obtained after enzyme digestion. In addition, the viability of recovered cells after storage at low temperature was ca. $90 \%$ in $60 \%$ glycerol plus $1.3 \mathrm{M}$ DMSO (Fig. 7). Furthermore, the intermediate thawing step, at $-20^{\circ} \mathrm{C}$, favoured cell survival, as without this step $P$. oceanica cells showed poor viability (Fig. 8).

Cell encapsulation has also been our specific interest given that encapsulated cells are a good attempt to overcome problems intrinsically associated with in vitro micropropagation such as salinity acclimation. Thus, encapsulated cells can mimic seeds and are suitable for vegetative propagation. Sodium alginate was chosen for cell encapsulation of $P$. oceanica seagrass, revealing firm, clear and isodiametric beads (Fig. S3). Additionally, the integrity of the bead can also be maintained over time. Encapsulated cells of $P$. oceanica stored for more than 1 yr show only a nonsignificant drop in germination percentage of less than $2 \%$ (Table 1 ).

Beyond this, our study shows that encapsulated cells do not lose their capacity to grow, implying that minerals, sugars and growth regulators of the MS medium can diffuse across an alginate barrier. Moreover, cell encapsulation presents other advantages, as it prevents cell aggregation, and beads are easily handled with less risks of physical damage due to sub-culturing and in vitro cell maintenance and microbial contamination. Notably, encapsulated cells can also be easily acclimated to salinity in contrast with non-encapsulated cells of both $P$. oceanica and $C$. nodosa (Zarranz et al. 2012), which are unable to grow and die. We are led to infer that the response of encapsulated cells of $P$. oceanica to gradual salinity acclimation could be a consequence of the presence of different osmotically regulated receptors and the modification of receptor signaling intensity in a dependent manner as cell growth occurred. For instance, a study on mechanisms related to water transport in P. oceanica showed differential expression of 2 aquaporin-encoding genes according to hypo- and hypersalinity conditions (Maestrini et al. 2004). Moreover, assuming that signalling occurs through the transport of charged particles, the signalling response of $P$. oceanica could depend on the dose and intensity of the stimulus (i.e. salt concentration).

All in all, encapsulated cells can somehow epitomise the whole plant in comparison with non-encapsulated cells. Encapsulated cells, just like whole plants, can be acclimated to salinity gradually (they can live in sea water), while free cells would exhibit emergency responses related to salinity acclimation (they need to acquire structural support in a short time period). As acclimation to salinity advanced, different stages of embryogenic masses, namely preand full embryos (Fig. 11A, Fig. S2C,D), were promoted by IBA. Nonetheless, the low rate of sprouting reported in embryos remains to be solved since preembryos and embryos seem to have high water content in P. oceanica. In terrestrial plants, sprouting frequency decreases with an increase in storage period, which is attributed to loss of moisture as a consequence of partial desiccation during storage (Danso \& Ford-Lloyd 2003) and due to different genotypes and embryo sizes (Tsai \& Saunders 1999). The low rate of sprouting could be further tackled with the quality of the encapsulated cells. In either of these ways, encapsulated cells of $P$. oceanica present an interesting framework in which to study the transition from embryos to plantlets. 
In conclusion, this work highlights the maintenance of cells at low temperature and cell encapsulation. Encapsulation is a benchmark towards the establishment of embryo cultures and further in vitro propagation of $P$. oceanica.

Acknowledgements. This research was supported by the collaboration of the Ministerio de Ciencia, Innovación y Universidades and the Universidad de Las Palmas de Gran Canaria (Grant CGL2016-78442-C2-2-R, GOBESP2017-04 ULPGC to P.G.J). M.C.A was supported by a predoctoral fellowship granted by the University of Las Palmas de Gran Canaria (ULPGC2016).

\section{LITERATURE CITED}

Ali M, Mujib A, Zafar N, Tonk D (2018) Protoplast isolation and plant regeneration in two cultivated coriander varieties, Co-1 and RS. BioTechnologia 99:345-355

Balestri E (2004) Flowering of the seagrass Posidonia oceanica in a north-western Mediterranean coastal area: temporal and spatial variations. Mar Biol 145:61-68

Balestri E, Cinelli F (2003) Sexual reproductive success in Posidonia oceanica. Aquat Bot 75:21-32

Balestri E, Piazzi L, Cinelli F (1998) In vitro germination and seedling development of Posidonia oceanica. Aquat Bot 60:83-93

Balestri E, Vallerini F, Lardicci C (2017) Recruitment and patch establishment by seed in the seagrass Posidonia oceanica: importance and conservation implications. Front Plant Sci 8:1067

Danso KE, Ford-Lloyd BV (2003) Encapsulation of nodal cuttings and shoot tips for storage and exchange of cassava germplasm. Plant Cell Rep 21:718-725

Garcia-Jimenez P, Navarro EP, Santana CH, Luque A, Robaina RR (2006) Anatomical and nutritional requirements for induction and sustained growth in vitro of $C y$ modocea nodosa (Ucria) Ascherson. Aquat Bot 84:79-84

Hemminga MA, Duarte CM (2000) Seagrass ecology. Cambridge University Press, Cambridge

Kilminster K, McMahon K, Waycott M, Kendrick GA and others (2015) Unravelling complexity in seagrass systems for management: Australia as a microcosm. Sci Total Environ 534:97-109

Lei R, Qiao W, Hu F, Jiang H, Zhu S (2015) A simple and effective method to encapsulate tobacco mesophyll protoplasts to maintain cell viability. MethodsX 2:24-32

Maestrini P, Giordani T, Lunardi A, Cavallini A, Natali L (2004) Isolation and expression of two aquaporin-encoding genes from the marine phanerogam Posidonia oceanica. Plant Cell Physiol 45:1838-1847

Molenaar H, Meinesz A (1995) Vegetative reproduction in Posidonia oceanica: survival and development of transplanted cuttings according to different spacing, arrange-

Editorial responsibility: Brant Touchette,

Elon, North Carolina, USA

Reviewed by: 3 anonymous referees ments and substrates. Bot Mar 38:313-322

Murashige T, Skoog F (1962) A revised medium for rapid growth and bio assays with tobacco tissue cultures. Physiol Plant 15:473-497

Nalawade SM, Sagare AP, Lee CY, Kao CL, Tsay HS (2003) Studies on tissue culture of Chinese medicinal plant resources in Taiwan and their sustainable utilization. Bot Bull Acad Sin 44:79-98

Orth RJ, Harwell MC, Bailey EM, Bartholomew A and others (2000) A review of issues in seagrass seed dormancy and germination: implications for conservation and restoration. Mar Ecol Prog Ser 200:277-288

Pandey A, Chand S (2004) Efficient plant regeneration from encapsulated somatic embryos of Hyoscyamus muticus L. Indian J Biotechnol 4:546-550

Papenbrock J (2012) Highlights in seagrasses' phylogeny, physiology, and metabolism: What makes them special? Int Sch Res Not 2012:103892

Patel AV, Pusch I, Mix-Wagner G, Vorlop KD (2000) A novel encapsulation technique for the production of artificial seeds. Plant Cell Rep 19:868-874

Pegg DE (2007) Principles of cryopreservation. In: Day JG, Stacey GN (eds) Cryopreservation and freeze-drying protocols, 2nd edn. Humana Press, Totowa, NJ, p 39-57

* Pongchawee K, Na-Nakorn U, Lamseejan S, Poompuang S, Phansiri S (2006) Factors affecting protoplast isolation and culture of Anubias nana Engler. Int J Bot 2:193-200

Possingham HP, Bode M, Klein CJ (2015) Optimal conservation outcomes require both restoration and protection. PLOS Biol 13:e1002052

Rai MK, Asthana P, Singh S, Jaiswal VS, Jaiswal U (2009) The encapsulation technology in fruit plants - a review. Biotechnol Adv 27:671-679

* Ruiz JM, Marín-Guirao L, García-Muñoz R, Ramos-Segura A and others (2018) Experimental evidence of warminginduced flowering in the Mediterranean seagrass Posidonia oceanica. Mar Pollut Bull 134:49-54

Staal M, Prins HBA, Harmelen MV, Helder RJ (1988) The isolation of leaf protoplasts from the submerged aquatic angiosperm Potamogeton lucens L. Plant Cell Environ 11:715-719

* Tsai CJ, Saunders JW (1999) Encapsulation, germination and conversion of somatic embryos in sugarbeet. J Sugar Beet Res 36:11-32

*Winkelmann T, Meyer L, Serek M (2004) Germination of encapsulated somatic embryos of Cyclamen persicum. HortScience 39:1093-1097

Zarranz ME, Gonzalez-Henriquez N, Garcia-Jimenez P, Robaina RR (2010) Restoration of Cymodocea nodosa (Uchria) Ascherson seagrass meadows through seed propagation: seed storage and influences of plant hormones and mineral nutrients on seedling growth in vitro. Bot Mar 53:439-448

Karranz ME, García-Jiménez P, Robaina RR (2012) Endogenous polyamine content and photosynthetic performance under hypo-osmotic conditions reveal Cymodocea nodosa as an obligate halophyte. Aquat Biol 17:7-17

Submitted: March 4, 2020

Accepted: November 2, 2020

Proofs received from author(s): February 25, 2021 